\title{
GROUPING OF PROVINCES IN INDONESIA BASED ON MATERNAL HEALTH INDICATORS USING VARIABLE WEIGHTING K-MEANS AND FUZZY C-MEANS
}

\author{
Elvira Mustikawati Putri Hermanto \\ Statistical Study Program, Faculty of Math and Science, Universitas PGRI Adi Buana Surabaya, 60234 Surabaya, \\ East Java, Indonesia \\ Corresponding Author: Elvira Mustikawati Putri Hermanto \\ E-mail: elvira.mustikawati@gmail.com
}

\begin{abstract}
Maternal Mortality Rate (MMR) is an indicator used to assess maternal health as well as the health status of a country. MMR is a target that must be achieved by Indonesian Government in Sustainable Development Goals (SDGs) in 2030. The Government of Indonesia has made various efforts to reduce MMR. This study aims to determine the distribution pattern of indicators for improving maternal health by grouping provinces in Indonesia based on the characteristics of maternal health indicators. The variables used are indicators that affect maternal mortality, namely $\mathrm{K} 4$ coverage $\left(\mathrm{x}_{1}\right)$, Td2+ immunization coverage $\left(\mathrm{x}_{2}\right)$, maternity assisted by health workers in health facilities coverage $\left(\mathrm{x}_{3}\right)$, post-partum check up coverage $\left(\mathrm{x}_{4}\right)$, Puskesmas implementing pregnant classes $\left(\mathrm{x}_{5}\right)$, Puskesmas implementing P4K $\left(\mathrm{x}_{6}\right)$, participant of $\mathrm{KB}$ coverage $\left(\mathrm{x}_{7}\right)$ in Indonesia in 2017 . The grouping methods are Variable Weighting K-Means (VWKM) and Fuzzy C-Means (FCM). The selection of the best grouping results uses the Internal Cluster Dispersion Rate (icdrate). Based on the analysis results, the best grouping is generated by the FCM method. The icdrate value generated by FCM is 0.325 while the icdrate value generated by VWKM is 0.552. FCM produces five groups which can be categorized as groups with maternal health indicator characteristics with very low, low, medium, high, and very high scores. Provinces in a group tend to be geographically close. East Java and Bali are provinces included in the indicator group of very high maternal health. Papua and West Papua fall into the group for maternal health which is very low.
\end{abstract}

Keywords: maternal health indicators, variable weighting k-means, fuzzy c-means, internal cluster dispersion rate

\begin{abstract}
ABSTRAK
Salah satu indikator yang digunakan sebagai ukuran untuk menilai program kesehatan ibu sekaligus derajat kesehatan suatu negara adalah Angka Kematian Ibu (AKI). AKI merupakan salah satu target yang harus dicapai oleh Pemerintah Indonesia dalam Sustainable Development Goals (SDGs) tahun 2030. Berbagai upaya dilakukan oleh pemerintah Indonesia untuk mencapai kesejahteraan kesehatan ibu untuk mengurangi AKI. Penelitian ini bertujuan untuk mengetahui pola sebaran dari indikator upaya peningkatan kesehatan ibu dengan melakukan pengelompokkan provinsi-provinsi di Indonesia berdasarkan karakteristik indikator kesehatan ibu. Variabel yang digunakan adalah variabel yang dianggap sebagai indikator yang mempengaruhi kematian ibu, yaitu cakupan K4 $\left(x_{1}\right)$, cakupan imunisasi Td2+ ( $\left.x_{2}\right)$, cakupan ibu bersalin di fasilitas kesehatan yang ditolong tenaga kesehatan $\left(x_{3}\right)$, cakupan kunjungan nifas $\left(x_{4}\right)$, puskesmas yang mempunyai program kelas hamil ( $\left.x_{5}\right)$, dan puskesmas yang mempunyai program orientasi Program Perencanaan Persalinan dan Pencegahan Komplikasi atau P4K $\left(x_{6}\right)$, cakupan peserta $K B$ aktif $\left(x_{7}\right)$ di Indonesia pada Tahun 2017. Metode pengelompokan yang digunakan adalah Variable Weighting K-Means (VWKM) dan Fuzzy C-Means (FCM). Pemilihan hasil pengelompokan terbaik menggunakan Internal Cluster Dispertion Rate (icdrate). Berdasarkan hasil analisis, pengelompokkan terbaik dihasilkan oleh metode FCM. Nilai icdrate FCM sebesar 0.325 sedangkan icdrate VWKM sebesar 0.552. FCM menghasilkan lima kelompok yang dapat dikategorikan sebagai kelompok dengan karakteristik indikator kesehatan ibu sangat rendah, rendah, sedang, tinggi, dan sangat tinggi. Provinsi yang ada dalam satu kelompok cenderung memiliki kedekatan lokasi geografis. Provinsi Jawa Timur dan Bali merupakan provinsi yang masuk dalam kelompok indikator kesehatan ibu sangat tinggi. Sedangkan Provinsi Papua dan Papua Barat masuk ke dalam kelompok indikator kesehatan ibu sangat rendah.
\end{abstract}

Kata kunci: indikator kesehatan ibu, variable weighting k-means, fuzzy c-means, internal cluster dispertion rate

Received: August 29, 2019

Accepted: November 22, 2019 


\section{INTRODUCTION}

In 2000, Indonesia agreed to a Millennium Development Goals (MDGs). There are several objectives, one of which is to improve maternal health by reducing the maternal mortality ratio in childbirth by three-quarters from 1990 in 2015. The target to be achieved by the MDGs is a maternal mortality ratio of around 110 in 2015 (UNDP, 2008).

The maternal mortality rate (MMR) is still very high in the half of the MDG period. UNDP (2008) states that the maternal mortality rate in 2008 was 307 per 100,000 births. Indonesia failed to reach the target of maternal mortality ratio. It was noted that the MMR ratio in Indonesia in 2015 was 305 (Indonesian Ministry of Health, 2018).

In 2016, Indonesia agreed to an agreement to replace the MDGs, namely Sustainable Development Goals (SDGs) with a target that must be achieved by 2030. In the SDGs, the MMR target is 70 deaths per 100,000 births.

The degree of health and success of a country's health program can be seen from the MMR. Various attempts have been made by the Indonesian government to achieve maternal health welfare to reduce MMR, one of which is to ensure that every mother has access to good and quality health services (Indonesian Ministry of Health, 2018).

Tetanus infection is one of the causes of infant and maternal death (Indonesian Ministry of Health, 2018). The government has implemented the Tetanus-Diphtheria Toxoid immunization program (Td) in Women of Fertile Age (WFA) and pregnant women to prevent tetanus infection. Figure 1 shows that the coverage of Td5 immunization in WUS in Indonesia is still low, at $2.40 \%$. Figure 1 also shows that in 2017 the coverage of Td5 immunization in WUS in the provinces was still much below the Indonesian figure, including Gorontalo (0.44\%), West Papua (0.63\%), and Papua $(0.55 \%)$.

Maternal health services, which mean deliveries assisted by health workers in health facilities, are an effort to reduce maternal and infant mortality. Assisted delivery of health workers in health facilities is included in the 2015-2019 Ministry of Health Strategic Plan of the Republic of Indonesia as an effort to improve maternal health. The Strategic Plan Target (in Bahasa Indonesia is known as Renstra) from 2015 to 2019 initiated by The
Indonesian Ministry of Health in the coverage of delivery is assisted by health workers by $79 \%$. In 2017, the coverage of childbirth is assisted by health workers in several provinces in Indonesia, such as Maluku, North Maluku, Papua, and West Papua, which is lower than $79 \%$.

Cluster Analysis or group analysis is a statistical method for classifying observations that have similar characteristics to other observations in one cluster. Grouping can be done based on distance or similarity. There are methods in cluster analysis, i.e. hierarchical clustering, and non-hierarchical clustering (Johnson and Wichern, 2007).

$K$-Means is an algorithm in nonhierarchical clustering which is commonly used in nonparametric methods. In the K-Means method, the observations will be precisely clustered into one cluster or not overlapping (Sharma, 1996). There are weaknesses of KMeans, namely there is no basis for determining the optimal number of groups (clusters), no initialization for the cluster center, and no determining the variables or key attributes in cluster formation.

Variable Weighting K-Means (VWKM) is a development of K-Means by Huang et al. (2005). In the VWKM method, each variable in the cluster has a weight. The weight generated in VWKM is used to find out the most important variables of all variables used in a cluster (Huang et al., 2005). Baswade et al. (2012) state that low weight variables can be removed so that the results of grouping will be better by using the remaining variables.

Several studies have been carried out using the VWKM algorithm. VWKM is used to classify text data (Jing et al., 2006). Hung et al. (2011) using the VWKM algorithm with color image segmentation. Research conducted by Huang et al. (2005) VWKM produces greater accuracy than the accuracy produced by $\mathrm{K}$ Means. The study concluded that VWKM is better than K-Means.

One of the development methods from KMeans is Fuzzy C-Means (FCM). In fuzzy clustering, the point that is close to the center of the cluster will likely have a higher degree of membership than the point on the edge of the cluster. In FCM, group membership is determined by the degree of membership with a numerical value between 0 and 1 (Kassambara, 2017). FCM can handle outlier data and allows observation to fit into more than one group 
(Mingoti and Lima, 2006). Based on research conducted by Mingoti and Lima (2006), FCM has the best results than K-Means and SOM. Research using the FCM method and K-means was also conducted by Ghosh and Dubey (2013) and Cebeci and Yildiz (2015).

In this study, provinces in Indonesia are grouped based on maternal health indicators using VWKM and FCM. Provinces in one group have characteristics similarities in maternal health indicators. The results of VWKM will reveal which maternal health indicators form the most groups.

The results of the grouping of this study provide information on the distribution of maternal health indicators. Based on the results of the grouping, provinces included in the category of maternal health indicators vary from very low to very high. The results of this study provide an overview of the distribution of maternal health indicators which are able to pressure the MMR to reach the target of the Strategic Plan of the Ministry of Health and SDGs in 2030.

\section{METHODS}

The data was taken from the publication of Republic of Indonesia Health Profile 2017 data. The variable used was the variable considered as an indicator that affects maternal mortality. These variables are the percentage of K4 coverage $(\mathrm{x} 1)$, percentage of $\mathrm{Td} 2+$ coverage (x2), percentage of maternal coverage assisted by health workers in health facilities $(\mathrm{x} 3)$, percentage of post-partum visit coverage $(\mathrm{x} 4)$, percentage of Puskesmas implementing pregnant classes (x5), percentage of Puskesmas implementing $\mathrm{P} 4 \mathrm{~K}$ ( $\mathrm{x} 6$ ), percentage of active $\mathrm{KB}$ participant $(\mathrm{x} 7)$ coverage in Indonesia in 2017.

This study aims to classify provinces in Indonesia based on the seven indicators of determinants of maternal health using two methods, namely, VWKM and FKM. Each province in one cluster has a similarity in characteristics of seven maternal health indicators. The best selection method for grouping results uses the Internal Cluster Dispersion Rate (icdrate) method. The value of icdrate is used to measure the spread of data in a group. The expected value is as small as possible to show the homogeneity of data in one group.
MANOVA analysis was conducted on the best grouping results to find out whether there were statistically significant differences in the mean values of maternal health indicators in the groups formed.

\section{RESULT}

Results of the analysis of data published in Indonesian Health Profile 2017 noted that the average percentage of $\mathrm{K} 4$ coverage is equal to $79.690 \%$. West Papua is the province with the lowest percentage of mothers doing $\mathrm{K} 4$ by $23,190 \%$. The largest variation of data occurred at $\mathrm{x} 2$ which showed that there was a significant gap among provinces with the lowest percentage of $\mathrm{Td} 2+$ coverage (North Sumatra with a value of $10.520 \%$ ) and the highest $\mathrm{Td} 2+$ coverage (South Sumatra by 104.710\%).

Grouping using VWKM forms three groups. Figure 1 shows the variable importance of each group. The variable captions are to the right of the image while the group captions are to the bottom of the image. The variables that make up the most groups are colored differently.

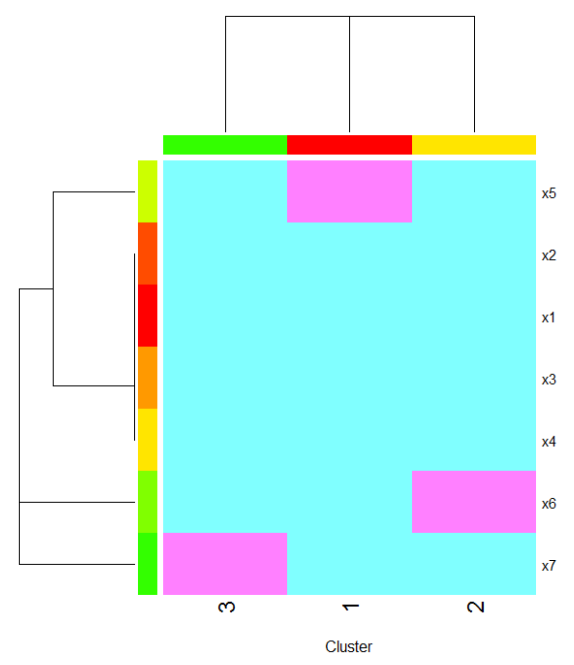

Figure 1. Visualization of Variable Importance in Each Group

Figure 1 shows that the indicators of the Puskesmas implementing the pregnant class (x5) are the most important in group 1 because $\mathrm{x} 5$ is a variable in purple. Indicators of Puskesmas implementing P4K (x6) and coverage indicators for active family planning participants (x7) are the indicators that most form groups 2 and group 3 . 
Table 1 Indicator Weight Value in Each Group

\begin{tabular}{cccccccc}
\hline Group & $\boldsymbol{x}_{\mathbf{1}}$ & $\boldsymbol{x}_{\mathbf{2}}$ & $\boldsymbol{x}_{\mathbf{3}}$ & $\boldsymbol{x}_{\mathbf{4}}$ & $\boldsymbol{x}_{\mathbf{5}}$ & $\boldsymbol{x}_{\mathbf{6}}$ & $\boldsymbol{x}_{\mathbf{7}}$ \\
\hline 1 & $1.43 \mathrm{E}-05$ & $1.43 \mathrm{E}-05$ & $1.43 \mathrm{E}-05$ & $1.43 \mathrm{E}-05$ & $1,00 \mathrm{E}+00$ & $1.43 \mathrm{E}-05$ & $1.43 \mathrm{E}-05$ \\
2 & $1.43 \mathrm{E}-05$ & $1.43 \mathrm{E}-05$ & $1.43 \mathrm{E}-05$ & $1.43 \mathrm{E}-05$ & $1.43 \mathrm{E}-05$ & $1,00 \mathrm{E}+00$ & $1.43 \mathrm{E}-05$ \\
3 & $1.43 \mathrm{E}-05$ & $1.43 \mathrm{E}-05$ & $1.43 \mathrm{E}-05$ & $1.43 \mathrm{E}-05$ & $1.43 \mathrm{E}-05$ & $1.43 \mathrm{E}-05$ & $1,00 \mathrm{E}+00$ \\
\hline
\end{tabular}

Table 2. VWKM Group Center

\begin{tabular}{cccccccccc}
\hline Cluster & $\boldsymbol{x}_{\mathbf{1}}$ & $\boldsymbol{x}_{\mathbf{2}}$ & $\boldsymbol{x}_{\mathbf{3}}$ & $\boldsymbol{x}_{\mathbf{4}}$ & $\boldsymbol{x}_{\mathbf{5}}$ & $\boldsymbol{x}_{\mathbf{6}}$ & $\boldsymbol{x}_{\mathbf{7}}$ & Category & $\begin{array}{c}\text { Important } \\
\text { indicator }\end{array}$ \\
\hline \multirow{2}{*}{1} & 84.869 & 41.101 & 72.203 & 86.196 & 94.893 & 76.136 & 56.024 & Medium & $x_{5}$ \\
& High & Medium & Medium & High & Medium & Medium & Medium & & \\
2 & 82.821 & 63.982 & 79.345 & 83.709 & 98.256 & 99.438 & 62.449 & High & $x_{6}$ \\
& Medium & High & High & Medium & High & High & High & & \\
\multirow{2}{*}{3} & 41.880 & 27.327 & 40.603 & 45.570 & 49.490 & 54.277 & 31.720 & Low & $x_{7}$ \\
& Low & Low & Low & Low & Low & Low & Low & Low & \\
\hline
\end{tabular}

The VWKM method can also group maternal health indicators. The results of the analysis with VWKM are known to have 4 groups of indicators. Figure 1 shows a dendrogram showing the formation of groups based on maternal health indicators found in Figure 1. Figure 1 shows that indicators $x 1, x 2$, $\mathrm{x} 3, \mathrm{x} 4$ can be included in one group because they have similar values to each other. Indicator $x_{5}, \mathrm{x} 6, \mathrm{x} 7$ form a separate group because it has its uniqueness.

Table 1. reinforces the information in Figure 1. Table 1 represents the value of indicator weights for each group. Figure 1 has shown that the variable $\mathrm{x} 5$ is an important variable in the formation of group 1 because the weight value for the pregnant class (x5) indicator that Puskesmas has implemented is the biggest weight compared to other variables, which is close to 1 . It means that indicator $\times 5$ is the indicator with the biggest weight of the most important in forming a group 1 . The value of the indicator Puskesmas implementing P4K (x6) in group 2 and the coverage indicator of active family planning participants $(x 7)$ in group 3 almost reach 1 (Table 1). This means that the two indicators are the main forming indicators for each group.

Group center is the average value produced at the end of group formation. Group center is obtained from the average value of the indicators of each province in one group. Group center for each group is shown in Table 2. Table 2 shows that cluster 3 can be categorized as a cluster with the lowest indicator value compared to the other two clusters. Cluster 1 and cluster 2 have high and medium indicator values.

Regrouping is done using the FCM method. Based on the FCM method it is known that the number of groups formed is five groups (Figure 2). Figure 2 shows that with FCM, provinces can be grouped into more than one group. Figure 2 shows that the Bangka Belitung (shown by number 9) can be classified into two groups, group 1 or group 2. However, Bangka Belitung is a province that is included in group 1 because the probability value of the Bangka Belitung grouped into group 1 is the biggest.

Table 3 shows that each group can be categorized into five categories, very low to very high. The first group can be categorized as a group that has the characteristic value of seven moderate maternal health indicators. Group five can be categorized as a group with a characteristic value of seven very low maternal health indicators.

The selection of the best grouping results performed by the icdrate group method with the FCM method is better compared to the VWKM. The icdrate value produced by FCM $(0.325)$ is smaller than VWKM (0.552). This means that maternal health indicator data in each group produced by FCM is more homogeneous than the group value produced by VWKM. In other words, the variation of data in a cluster produced by FCM is smaller than VWKM. 


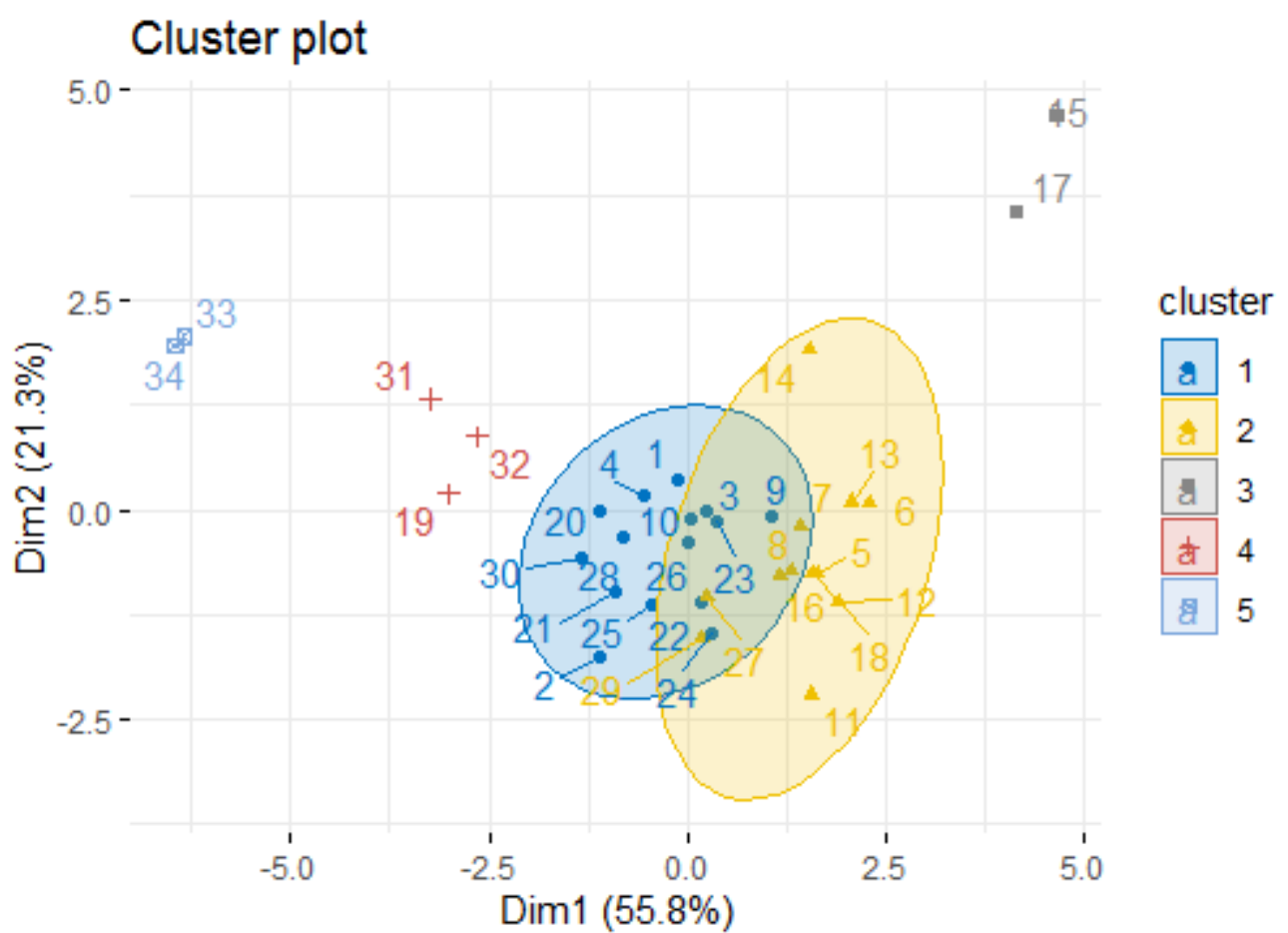

Figure 2. Clustering Visualization with FCM

Table 3. FCM Method Group Center

\begin{tabular}{|c|c|c|c|c|c|c|c|c|}
\hline Group & $x_{1}$ & $x_{2}$ & $x_{3}$ & $x_{4}$ & $x_{5}$ & $x_{6}$ & $x_{7}$ & Category \\
\hline 1 & $\begin{array}{c}79.772 \\
\text { (medium) }\end{array}$ & $\begin{array}{c}46.812 \\
\text { (low) }\end{array}$ & $\begin{array}{c}72.019 \\
\text { (medium) }\end{array}$ & $\begin{array}{c}81.368 \\
\text { (medium) }\end{array}$ & $\begin{array}{c}95.678 \\
\text { (medium) }\end{array}$ & $\begin{array}{c}92.202 \\
\text { (medium) }\end{array}$ & $\begin{array}{c}58.587 \\
\text { (medium) }\end{array}$ & Medium \\
\hline 2 & $\begin{array}{c}91.875 \\
\text { (very high) }\end{array}$ & $\begin{array}{c}71.538 \\
\text { (very } \\
\text { high) }\end{array}$ & $\begin{array}{c}86.620 \\
\text { (high) }\end{array}$ & $\begin{array}{c}90.078 \\
\text { (high) }\end{array}$ & $\begin{array}{c}99.395 \\
\text { (high) }\end{array}$ & $\begin{array}{c}99.598 \\
\text { (very } \\
\text { high) }\end{array}$ & $\begin{array}{l}65.117 \\
\text { (high) }\end{array}$ & High \\
\hline 3 & $\begin{array}{l}90.845 \\
\text { (high) }\end{array}$ & $\begin{array}{l}73.015 \\
\text { (high) }\end{array}$ & $\begin{array}{c}95.020 \\
\text { (very } \\
\text { high) }\end{array}$ & $\begin{array}{l}93.575 \\
\text { (very } \\
\text { high) }\end{array}$ & $\begin{array}{l}99.845 \\
\text { (very } \\
\text { high) }\end{array}$ & $\begin{array}{l}99.170 \\
\text { (high) }\end{array}$ & $\begin{array}{r}66.720 \\
\text { (very } \\
\text { high) }\end{array}$ & Very high \\
\hline 4 & $\begin{array}{l}53.897 \\
\text { (low) }\end{array}$ & $\begin{array}{c}49.053 \\
\text { (medium) }\end{array}$ & $\begin{array}{c}41.147 \\
\text { (very low) }\end{array}$ & $\begin{array}{l}61.023 \\
\text { (low) }\end{array}$ & $\begin{array}{c}88.933 \\
\text { (low) }\end{array}$ & $\begin{array}{c}64.663 \\
\text { (low) }\end{array}$ & $\begin{array}{c}43.587 \\
\text { (low) }\end{array}$ & Low \\
\hline 5 & $\begin{array}{c}33.505 \\
\text { (very } \\
\text { low) }\end{array}$ & $\begin{array}{c}14.280 \\
\text { (very } \\
\text { low) }\end{array}$ & $\begin{array}{l}45.580 \\
\text { (low) }\end{array}$ & $\begin{array}{c}39.955 \\
\text { (very low) }\end{array}$ & $\begin{array}{c}36.545 \\
\text { (very low) }\end{array}$ & $\begin{array}{c}44.230 \\
\text { (very } \\
\text { low) }\end{array}$ & $\begin{array}{c}27.630 \\
\text { (very } \\
\text { low) }\end{array}$ & Very low \\
\hline
\end{tabular}

The next analysis is to examine differences in the average value of maternal health indicators between-group results of the FCM method by using MANOVA analysis. The hypothesis from using MANOVA is as follows:

$H_{0}: \pi_{1}=\pi_{2}=\ldots=\pi_{5}$

$H_{1}$ : min ada satu $\pi_{i} \neq \pi_{j}, i, j=1,2, \ldots, 5$

$$
i \neq j
$$

where $\pi \mathrm{i}$ is the average indicator of each group. Based on the results of the analysis with MANOVA it can be concluded that there are differences in the average maternal health indicators at least in one group. This means that the characteristics of maternal health indicators in each group produced by FCM are different from other groups.

Figure 3 shows the results of grouping using the FCM method. In Figure 3, it can be seen that group 1 , which is a group with a moderate value indicator value, consists of all provinces in Kalimantan Island. Papua and West Papua are the provinces included in group 5 , which are clusters with very low maternal 
health indicator values. Based on Figure 3, it can be seen that provinces that fall into the same group tend to have geographical proximity. Group 3 is a group with very high maternal
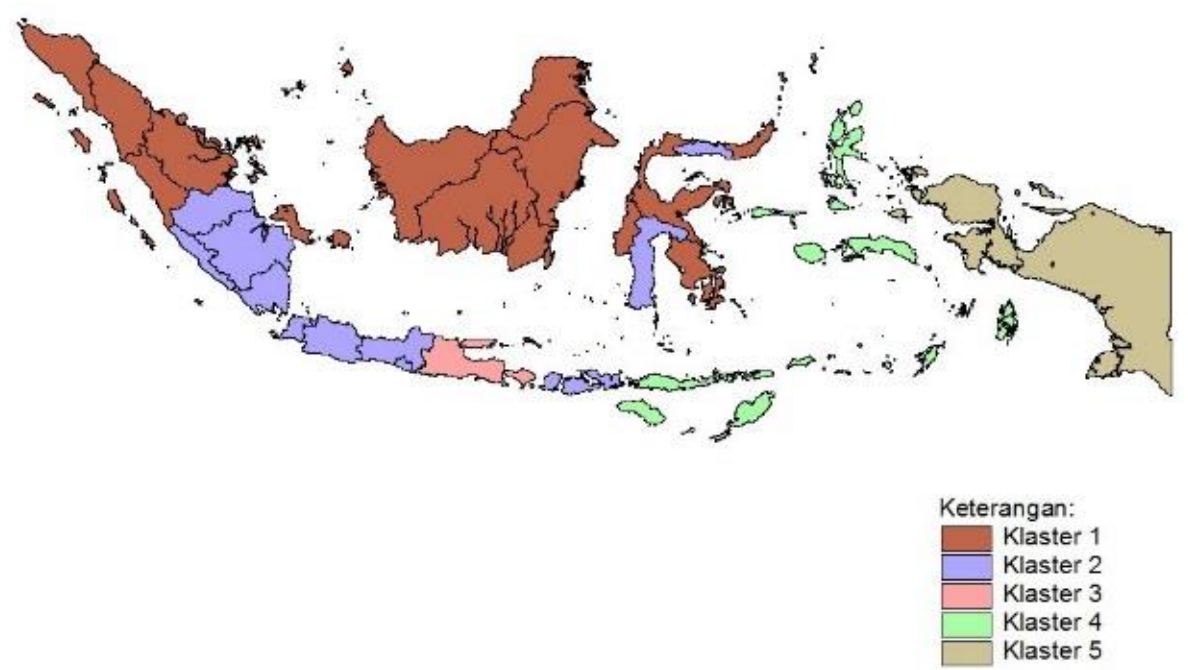

Figure 3. Mapping of Grouping Results with Fuzzy C-Means Method in Indonesian Province according to Maternal Health Indicators

health indicator values. Group 3 are East Java and Bali. Whereas Group 5, which are Papua and West Papua, grouped with a tendency to have very low maternal health indicator values. The characteristics of each group (cluster) can be seen in Table 3.

\section{DISCUSSION}

To achieve the AKI target set by SGDs, which is 70 deaths per 100,000 births, the Ministry of Health is implementing an Expanding Maternal and Neonatal Survival (EMAS) program. The EMAS program targets MMR and neonatal to decrease by $25 \%$. Efforts to reduce MMR by ensuring that every mother gets access to appropriate and quality health services, namely pregnancy health services, delivery services in health facilities assisted by trained health workers, post-partum care for mothers and infants, special care and referrals if there are complications, ease of obtaining leave pregnancy and childbirth, and family planning services (Indonesian Ministry of Health, 2018).

Based on information obtained from the Indonesia Health Profile 2017 book, it is explained that $\mathrm{K} 1$ and $\mathrm{K} 4$ coverage are indicators used to assess the health services for pregnant women. K4 (x1) coverage is the number of pregnant women who receive antenatal care according to the standard and the recommended schedule at least four times in each semester divided by the number of pregnant women in an area in one period (year). In 2017, 11 provinces in Indonesia had a percentage of K4 coverage below the target of the Indonesian Ministry of Health's Strategic Plan (Indonesian Ministry of Health, 2018).

Indonesian Ministry of Health (2018) states that Clostridium tetani is the bacterium that causes tetanus infection from the wounds of pregnant women before labor or unsafe labor. Tetanus infection is one of the causes of maternal and infant death. Therefore, the immunization of Tetanus-Diphtheria Toxoid (Td) for Women of Fertile Age (WFA) and pregnant women is one step to suppress tetanus infection. There were five times the $\mathrm{Td}$ immunization was given, divided into $\mathrm{Td} 1$ to $\mathrm{Td} 5 . \mathrm{Td} 2+$ is a group of mothers who received Td2 to Td5 immunizations. West Java, South Sumatra, and DI Yogyakarta are the provinces with the highest percentage of $\mathrm{Td} 2+(\mathrm{x} 2)$ coverage in Indonesia, which is more than $90 \%$. 
While North Sumatra, Papua, and West Papua are the three provinces with the lowest percentage of $\mathrm{Td} 2+$ coverage in Indonesia.

Another effort to suppress MMR is to seek delivery assisted by experts, such as obstetrics and gynecology specialists or midwives conducted in health facilities such as health centers and hospitals. Since 2015, delivery in health facilities has been determined by the Ministry of Health Strategic Plan (Renstra) Republic of Indonesia as an indicator of efforts to improve maternal health from 2015 to 2019 (Indonesian Ministry of Health, 2018). The strategic plan aims $79 \%$ of deliveries in Indonesia is assisted by experts and in health facilities. Based on available data it is known that there is a significant gap between DKI Jakarta and Maluku. All deliveries in DKI Jakarta are assisted by experts and in health facilities. While in Maluku, they are assisted by experts and only $30.65 \%$ done in health facilities. A total of 17 provinces in Indonesia did not fulfill the strategic plan target. Five provinces coverage of childbirth assisted by experts in health facilities $(\mathrm{x} 3)$ were recorded less than 50\%, including North Maluku, Maluku, West Papua, Papua, and Central Kalimantan.

Efforts to improve maternal health do not only extend to delivery. Post-delivery maternal coverage, post-partum mothers who receive health services, is one of the important indicators determined as an effort to improve maternal health. The percentage of post-partum visits (x4) in Indonesia from 2008 to 2017 experienced an upward trend. However, there was a decrease of $2.65 \%$ in 2016 and increased again to $87.36 \%$ in 2017. Papua and West Papua are provinces with post-partum maternal health care coverage of less than $50 \%$.

The percentage of Puskesmas that have a pregnant class program (x5) and the percentage of Puskesmas that have orientation programs for the Birth Planning and Prevention Complications Program or P4K (x6) are determined by the Indonesian Ministry of Health as an effort to reduce maternal and infant mortality rates (Indonesian Ministry of Health, 2018). Almost all provinces in Indonesia fulfill the strategic plan targets for the two indicators. West Papua and Papua are the two lowest provinces below $40 \%$ for indicators of Puskesmas implementing pregnant classes. While North Maluku, West Papua, and Papua are the lowest provinces for Puskesmas indicators that implement P4K below 50\%.

One step to reduce maternal mortality with the condition (1) Underage delivery (under the age of 20 years), (2) Frequent delivery, (3) Time gap for each delivery is too close, and (4) Too old to give birth (above age 35 years), is the Family Planning Program (KB). Therefore, monitoring of the percentage of active $\mathrm{KB}$ participant $(x 7)$ coverage continues. In Indonesia, $63.22 \%$ of fertile age couples attend the family planning program. Papua is one of the five lowest provinces covered by active family planning participants by $50 \%$.

Seven indicators used as efforts to improve maternal health in Indonesia are spread unevenly. In big cities, the percentage of coverage of maternal health indicators tends to be high. However, there are still many provinces that have indicator coverage under the Ministry of Health's Strategic Plan Republic of Indonesia. Therefore, it is necessary to group the provinces to determine the distribution of the seven efforts' indicators to improve maternal health. The results of grouping can make it easier to observe the condition of maternal health indicators in the territory of Indonesia.

Efendi et al. (2019) researched and classified Bengkulu based on health status with K-Means Clustering. The number of groupings obtained was three groups. The variable used is an indicator of health as measured by mortality. This study produced three clusters that can be divided into clusters with low, medium, and high mortality indicator values.

Purnama (2017) used the Fuzzy C-Means method to classify provinces in Indonesia according to health development indicators. The results of the study formed four clusters. The same member from each cluster is known to be close together in a location. All provinces in Java are included in the cluster with a very good health development indicator category.

Mustafidah (2017) compared the results of the grouping of districts/cities in Central Java Province according to poverty indicators using the C-Means and Fuzzy C-Means methods. Based on the results of the analysis obtained the optimum number of clusters are 5 clusters. The results of the grouping with the Fuzzy C-Means method are the best because the value of icdrate is small.

In this study, three clusters were formed using the method Variable Weighting K-Means 
(VWKM). The three clusters formed can be categorized into clusters with low, medium, and high-value maternal health indicator values. Based on the analysis results it is revealed that the coverage indicator Puskesmas implementing the pregnant class (x5) are the most significant indicators in forming cluster 1 , Puskesmas implementing P4K (x6) are the most significant in forming cluster 2 , the coverage of active $\mathrm{KB}$ participants $(\mathrm{x} 7)$ is the most significant in forming cluster 3.

Grouping or clustering provinces in Indonesia based on maternal health indicators is better to use the Fuzzy K-Means (FKM) method than variable Weighting K-Means (VWKM). That is because the ICDRate value generated by FKM is smaller than VWKM. In other words, the internal cluster produced by FKM is more homogeneous than VWKM.

FKM produces 5 clusters that can distinguish clusters with maternal health indicator values of very high value, high value, medium value, low value, and very low value. Based on the results of clustering, the provinces included in the indicator group of very low maternal health are Papua and West Papua. The percentage of the seven indicators used in improving maternal health in Papua and West Papua Provinces does not reach 50\%. The percentage of coverage of pregnant women implementing K4 in West Papua Province is very low. $23.19 \%$ of pregnant women get K4 health services in West Papua Province. Similarly, the percentage of $\mathrm{Td} 2+$ immunization coverage in West Papua Province is very low, which is only $12.51 \%$. This means that out of 100 women of fertile age, only 13 women have TD2 + immunization.

The provinces of East Java and Bali are two provinces that have similarities in seven indicators of maternal health, which can be classified into clusters with very high maternal health indicator values. All health centers registered in Bali carry out pregnancy and $\mathrm{P} 4 \mathrm{~K}$ classes. The awareness of mothers to obtain health services in the two provinces is very high. More than $90 \%$ of mothers in East Java and Bali deliver labor in health facilities assisted by experts. After the birth is over, the awareness of the mother to take part in childbirth visits is also high. $92.84 \%$ of mothers in East and $94.31 \%$ of mothers in Bali conducted OSH puerperal visits.

Based on the results of grouping with FKM, the provinces that are in one cluster are geographically close together. Mapping the results of the grouping can be used as a general description of the distribution of indicators for efforts to improve maternal health throughout Indonesia. It is hoped that the provinces included in the cluster with very low indicator scores get more attention from the government as an effort to equalize health indicators.

\section{CONCLUSIONS AND SUGGESTIONS}

\section{Conclusion}

Based on the results of clustering with Variable Weighting K-Means, it is known that indicators of health centers that have a pregnant class program (x5), health centers that have $\mathrm{P} 4 \mathrm{~K}$ (x6), active KB participant coverage (x7) are the three most important indicators in the formation of the three clusters produced. The grouping of provinces in Indonesia is based on the similarity of the characteristics of the best maternal health indicators produced by the Fuzzy K-Means method because the resulting icdrate value is minimum.

The Fuzzy K-Means method produced five clusters or groups. Characteristics of maternal health indicators can be grouped into groups with maternal health indicators which are very low, low, medium, high, and very high value. From the results of the grouping are known that Papua and West Papua can be included in very low cluster. Indonesia's government is expected to provide major interventions in efforts to improve maternal health indicators, especially in Papua and West Papua so that it can achieve the Ministry of Health's Restra targets that have been set.

\section{Suggestion}

Future studies can try to do grouping with other clustering methods to produce more optimal grouping results. As an effort to improve maternal health in Indonesia to achieve the SDGs target and the Ministry of Health Strategic Plan in 2019, the government can make stronger health interventions for provinces that fall into the category of clusters with very low and low indicator values.

\section{REFERENCES}

Baswade, A. M., Joshi, K. D., and Nalwade, P.S., 2012. A Comparative Study of KMeans and Weighted K-Means for 
Clustering. International Journal of Engineering Research \& Technology (IJERT), 1 (10), pp. 1-4.

Cebeci, Z., and Yildiz, F., 2015. Comparison of K-Means and Fuzzy C-Means Algorithms on Different Cluster Structures. Journal of Agricultural Informatics, 6 (3), pp. 13-23. https://doi.org/10.17700/jai.2015.6.3.196

Efendi, R., Coastera, F. F., and Tanjung, F., 2019. Pengelompokan dan Pemetaan Derajat Kesehatan Kota Bengkulu dengan Metode K-Means Clustering. Jurnal Rekursif, 7 (1), pp. 91-97.

Ghosh, S., and Dubey, S.K., 2012. A Comparative Analysis of Fuzzy C-Means Clustering and $\mathrm{K}$ Means Clustering Algorithms. International Journal of Computational Engineering Research, 2 (3), pp. 737-739.

Huang, J. Z., Ng, MK, Rong, H., and Li, Z., 2005. Automated Variable Weighting in KMeans Type Clustering. Journal of IEEE Transactions on Pattern Analysis and Machine Intelligence, 27 (5), pp. 657-668.

Hung, W., Chang, Y., and Lee, E. S., 2011. Weight Selection in W-K-Means Algorithm with an Application in Color Image Segmentation. Journal of Computers and Mathematics with Applications, 62 (2), pp. 668-676. https://doi.org/10.1016/j.camwa.2011.05.0 48

Jing, L., Ng, M. K., Yang, X., and Huang, J.Z., 2006. A Text Clustering System based on k-type Type Subspace Clustering and Ontology. International Journal of
Intelligent Technology, 1 (2), pp. 91-103.

Johnson, R.A., and Wichern, D.W., 2007. Applied Multivariate Statistical Analysis. 6th ed. New Jersey: Pearson Prentice Hall.

Kassambara, A., 2017. Practical Guide to Cluster Analysis in $R$ Unsupervised Machine Learning (1st ed.). sthda.com.

Indonesian Ministry of Health, 2018. Profil Kesehatan Indonesia Tahun 2017. Jakarta.

Mingoti, S. A., and Lima, J.O., 2006. Comparing SOM Neural Networks with Fuzzy C-means, K-means, and Traditional hierarchical clustering algorithms. European Journal of Operational Research, 174, pp. 1742-1759. https://doi.org/10.1016/j.ejor.2005.03.039

Mustafidah, R., 2017. Pengelompokan Kabupaten/Kota di Provinsi Jawa Tengah Berdasarkan Indikator Kemiskinan dengan C-Means dan Fuzzy C-Means Clustering. Thesis. Institut Teknologi Sepuluh Nopember.

Purnama, G. L., 2017. Pengelompokan Provinsi di Indonesia Berdasarkan Indikator Pembangunan Kesehatan Menggunakan Fuzzy C-Means Cluster. Thesis. Institut Teknologi Sepuluh Nopember.

Sharma, S., 1996. Applied Multivariate Techniques. Canada: John Wiley \& Sons, Inc.

UNDP, 2008. Millennium Development Goals. Retrieved from https://www.undp.org/content/dam/indone sia/docs/MDG/Let Speak Out for MDGs ID.pdf. 